\title{
Islamic Philanthropy : Waqf Empowerment of Madina Minimarket In Tasikmalaya - Indonesia
}

\author{
Asep Suryanto ${ }^{\mathrm{I}}$,Biki Zulfikri Rahmat ${ }^{2}$, Lina Marlina ${ }^{3}$ \\ Universitas Siliwangi ${ }^{1,2,3}$ \\ asepsuryanto@,unsil.ac.id ${ }^{1}$, bikizulfikrirahmat@, unsil.ac.id ${ }^{2}$, \\ $\underline{\text { linamarlina@,unsil.ac.id }}$
}

\begin{abstract}
The purpose of this study was to determine the implementation of productive waqf economic empowerment in the form of a minimarket in Purbaratu, Tasikmalaya City. Grouded research used to try to develop a concept through empirical exploration of the economic empowerment of productive endowments carried out by the City of Tasikmalaya Baznas so as to produce a conceptual description of the economic empowerment of productive waqf. The results showed that the Madina minimarket is an implementation of empowering productive waqf through business activities with the concept of the people for the people (social enterprise). Madina Minimarket is built on waqf land given by waqif to the Baznas Tasikmalaya City is used as fixed capital for minimarkets while working capital is obtained from investors. Every month, the profit earned by Madina minimarket is used to pay the minimarket employees and distributed to all mosques in Purbaratu District neighborhood in the form of shopping vouchers for mosque needs.
\end{abstract}

Keywords : IslamicPhilanthropy, Empowerment, Waqf

\section{A. INTRODUCTION}

Islamic philanthropy is a form of community philanthropy that aims not only to fulfill religious obligations as a command of Allah SWT, but also to help fellow disadvantaged communities, so that the community will be prosperous. The practice of Islamic philanthropy in the context of waqf in Indonesia already existed 
when Islam entered. However, the existing practice is only in the form of land, mosques, grave and so on, so that the management of philanthropic institutions cannot be optimal in helping the poor.

Waqf as one of the Islamic social institutions is closely related to the socioeconomic community. Although waqf is an Islamic institution that is legally fiqh, but it can develop well in several countries such as Egypt, Jordan, Saudi Arabia and Bangladesh. This is probably because this waqf institution is managed with good management. Thus it provides benefits that can be felt by those who need it.

The potential of waqf in Indonesia according to the Directorate of Empowerment of Zakat and Waqf, is quite large, whether in the form of land, money, or goods with individual or corporate waqf. Much waqf is not optimally managed. The number of waqf land alone in Indonesia is 367,716 locations with an area of 49,630.19 $\mathrm{Ha}$. Of the total $62 \%$ of them are already endorsed, I0\% have high economic potential, and many more are not yet recorded (Dirjen Bimas Islam, 2018). Waqf land managed productively in the form of business is still small, even though the results can be utilized for those who need it, including the poor. So far, the use of new waqf land from social aspects, especially for religious purposes, but the impact is less positive on the economic life of the community.

If the designation of waqf is limited only to these matters and is not balanced with waqf that can be managed productively, then waqf as one of the means to realize the socio-economic welfare of the community will not be realized optimally. Waqf has only been managed consumptively and traditionally. In order for waqf to be empowered for the economy of the ummah, a new paradigm of waqf management is needed, namely productive and professional management.

The emergence of an exciting new era for the development of Islamic philanthropy is marked by the emergence of Islamic philanthropic institutions from civil society that carry out collective management of zakat, infaq, alms (shadaqah), and waqf in a professional and transparent manner. The raising of Islamic philanthropic funds is then followed by increasingly effective and productive utilization. Islamic philanthropy has transformed from the level of charity-socialindividual to the level of economic-development-publicity. The managers of Islamic philanthropic funds (zakat, donation, alms and waqf) appear everywhere and are managed more structured and some of them are very professional. The philanthropic institution that began to grow, especially since the late 90s was able to manage funds in community empowerment and poverty alleviation programs in a patterned and sufficiently measurable way. 
In Indonesia, Islamic philanthropy is driven by the social activities of the two most important religious institutions namely mosques and Islamic boarding schools, therefore a major change is needed in the paradigm and behavior of donors and increasing the capacity of fundraising institutions for better Islamic philanthropic performance going forward. A philanthropist is expected to be able to choose or distribute funds through an authorized institution or more trustworthy in its distribution, for example through zakat and waqf institutions. Likewise, the institutions that have managed the funds can manage well and in their distribution are truly on target so that what the goal of Islamic philanthropy is can be more achieved.

Tasikmalaya is known as the City of Santri, especially in the era before the I980s because almost throughout the region scattered boarding schools that teach Islam, both large and small huts, can even give birth to national struggle figures including Zainal Mustafa. Tasikmalaya when viewed from the aspect of sociocultural conditions proved to have a strong community structure based on Islam with a population of $98.43 \%$ Muslim. This social life based on Islam makes tolerance and the strength of the principle of mutual cooperation and kinship. This is supported by the structure of the community which has an original Sundanese Priangan background causing inter-religious harmony guaranteed.

Potential waqf in the City of Tasikmalaya is quite a lot, namely there are I,679 locations with an area of 8I.20 hectares spread in I0 Districts. This can be seen in the following picture:

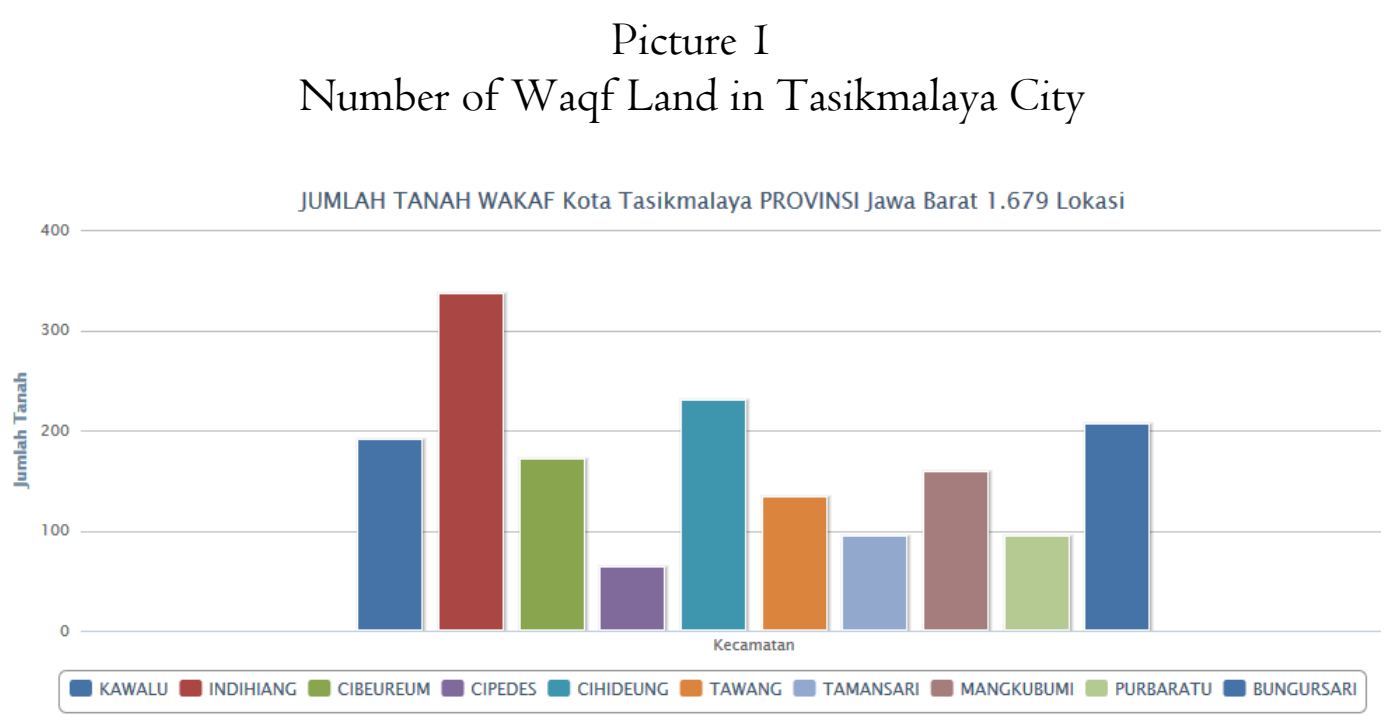

https://ejournal.radenintan.ac.id/index.php/ikonomika 
The potential number of locations and the area of waqf land in the City of Tasikmalaya if managed productively will certainly contribute to the development of the city of Tasikmalaya. Unfortunately, this potential is not accompanied by good management of waqf. Nevertheless, the Baznas Tasikmalaya City since 2016 has begun to develop productive waqf management by creating a pilot project in Purbaratu, Tasikmalaya City.

Waqf has a significant role in national economic development. This can be seen when waqf is managed productively and professionally. Some countries whose productive waqf management can support the development of their country, both in alleviating poverty, providing employment, improving the quality of human resources in the form of educational scholarships and so on. However, on the other side of management issues, the community's understanding of waqf is still lacking and has an impact on idle assets so that it becomes unproductive, ultimately not having a multiplayer effect on the ummah economy.

Thus the research on the economic empowerment of productive waqf especially in Tasikmalaya becomes very important to be carried out in order to know the productive management of waqf and its problems.

\section{B. THEORICAL}

\section{Definition of Waqf Economics}

Etymologically the word waqf comes from waqafa, yaqifu, waqfan which means standing upright, holding, stopping. The word waqafa means al habsu that means to hold, prevent or obstruct. If it is said wafaqtu kadza it means habastuhu, that is, I am holding back something. In terms of syara 'waqf is defined(Muhammad bin Ismail, I995)

$$
\text { حبس مال يمكن الانتفاع به مع بقاء عينه، بقطع التصرف فى رقبته على مصرف مباح }
$$

"Hold the valuable items that can be taken advantage of paired goods are still intact, by limiting the use of only certain allocations that are allowed".

Therefore, waqf means to retain property that might be taken advantage of without spending or damaging the substances and used it for good. Waqf is the containment of objects over the property of people who are charitable and offer their benefits for good purposes(Wahbah az Zuhaily, I985). More simply (Hasan Ayub, 2006) mentions the meaning of waqf:

$$
\text { تحبيس الأصل وتسبيل الثمرة (أي إنفاقها في سبيل من سبيل الخير) }
$$

"Withholding the principal of the waqf property and releasing or developing the results, that is, giving it to the path of goodness". 
The concept of waqf shows that the purpose of waqf gives a portion of its wealth to endowment for charitable purposes and as financial assistance for those in need. After the assets are donated in the form of waqf, then the donated property belongs to Allah SWT and the conditions determined by the waqf must be strictly followed by management or nadzir (waqf administrator)(Yusuff Jelili Amuda, 2013).

The Islamic definition of waqf makes waqf assets continue to accumulate in accordance with the application of the principle of eternity in waqf. This means that waqf principal assets cannot be sold or disposed of in any form, meaning that waqf property remains in the domain of endowments and every new waqf will be added to that domain, implying that the nature of waqf is only possible to increase. They are not permitted to reduce waqf property because it is illegal to consume waqf property or leave it idle because of an act of neglect or violation(Noor Aimi Bt Mohd Puad, at all, 20I4).

\section{Productive Waqf and Economic Empowerment of the Ummah}

Waqf has an important role as an instrument in empowering the economic community. In history, waqf has played an important role in the social, economic and cultural development of the community. Wealth is transferred from private ownership to collective ownership through waqf mechanisms with the aim of religion, education, or other benevolent purposes in accordance with certain terms and conditions(Nasim Shah Shirazi, 20I4). Other things that stand out the most from waqf institutions are their role in financing various Islamic education and health.

Productive Waqf is generally in the form of agricultural land or plantations, commercial buildings that are managed productively so that it brings profits, some of which results are used to finance various activities of the people. Thus the waqf property is really a source of funds from the community for the community(Muhammad Yusuf, 2009).

The narrow community understanding of the assets represented is only limited to immovable objects and only for religious purposes, such as mosques, prayer rooms, madrassas, funerals, etc. They will have an impact on the productivity of the management of waqf assets. The use of waqf assets in Indonesia according to the waqf information system of the Ministry of Religion of the Republic of Indonesia is mostly used for prayer rooms, mosques and cemeteries (77.75\%) compared to schools and pesantren (13.85\%) and other social facilities $(8.40 \%)$. While the results of Aam's study show that in the perspective of the waqf 
field of education and health is the first and second priority in the development of waqf in Indonesia (Aam Slamet Rusydiana, at. al., 2019). Realizing the main goal of waqf is to optimize the function of waqf property as infrastructure to improve the quality of life and life of human resources, it is necessary to change the understanding of Muslims about the role and function of waqf for the ummah.

The most important characteristic of waqf is related to the purpose of waqf itself, that is, the idea of doing good (doing good deeds). The purpose of waqf may be for the wider community, including the provision of religious services, socioeconomic assistance to segments of the community in need, the poor, education, the environment, scientific, and other objectives approved by sharia(Habib Ahmed, 2007).

Efforts to manage waqf land productively, the role of nazhir waqf either individuals or legal entities that are given the task of managing waqf are needed. Nazhir has the responsibility and obligation of maintaining and developing waqf and distributing the results and benefits of endowments to waqf targets. Waqf assets managed by nadzir which incompetence do not have adequate capabilities, causes waqf assets are not managed optimally and do not provide benefits to waqf targets.

In the terminology of jurisprudence among Nazir conditions other than Islam and mukallaf, they have the ability to manage waqf (professional) and have a trustful, honest and fair nature. When the waqf property is managed optimally and Nazir as a waqf manager has sufficient capability, then the multiplayer effect of waqf in empowering civil society is expected to be achieved. In addition, the government must push politically through waqf laws and regulations so that waqf can function productively. The government must intervene to help strengthen the waqf agenda, at least play the role of the facilitator in ensuring that the waqf development process is more efficient so that the benefits of waqf can be achieved. Successful waqf initiatives can help ease the burden on the government in providing public services, especially in empowering civil society (Norma Md Saad, et.all, 2017).

\section{Waqf Empowerment}

Islam as the only religion that applies the concept of waqf. Waqf in the Muslim world must play a very important role in social, political, and economic life in Muslim societies. Thus, waqf must be the main vehicle in encouraging people to achieve peace and tranquility, to provide good food, higher education, to serve free health services and so on. Therefore, waqf institutions must play their role 
effectively in ensuring waqf as an important instrument in improving socioeconomics especially in efforts to eradicate poverty for the welfare of Muslims. This role must be understood based on Maqasid al-Sharia, which is to uphold justice in serving the public (Noor Aimi Bt Mohd Puad, at all, 2014).

An alternative investment model that can be used by Nadzir in managing productive waqf can be direct investment in the real sector and monetary instruments. Things that can be taken into consideration in determining the investment construction of waqf fund management must meet the following criteria: I) alternative investment instruments must be Sharia compliant; 2) must be able to maintain the objectives of waqf management; 3) able to maintain the security of the principal investment (source of waqf funds); 4) able to provide optimal returns; and 5) able to reduce risk to a minimum (Ai Nur Bayinah, 2012).

Tan Sri Ali Hashim outlines six models of waqf companies that can be done in the development of waqf assets, namely: (I) business entities or corporations, (2) banking and financial institutions, (3) universities, (4) foundations, (5) cooperatives, and (6) hospitals or clinics. Waqf companies structured in business and banking companies and financial institutions have been implemented in Malaysia by Johor Corporation (JCorp) and Bank Muamalat Malaysia Berhad. In 2006 JCorp launched the idea of "Corporate Waqaf", through its waqf company agenda as reported in 2007. JCorp dedicated 25\% of annual dividend payments from shares transferred to waqf. The dividend is used to regulate various Muslim and non-Muslim activities and organize charitable and religious activities that are beneficial and meet the needs of the community as a whole (Asharaf Mohd Ramli and Abdullaah Jalil, 2013).

Law number $4 \mathrm{I}$ of 2004 states about waqf that nadzir must manage and develop waqf property in accordance with the purpose, function and designation of waqf. This implies that waqf must be managed productively, so that waqf property can develop and provide benefits to the people. Therefore, waqf management must follow the principles (Juhaya S. Praja, Muzarie Mukhlisin, 2009) as follows: I) Waqf management must be in accordance with sharia principles; 2) Waqf management must be done productively; 3) If the management of waqf requires a guarantor, then it must use a sharia guarantor; 4) For waqf neglected or waqf assets originating from individual waqif citizens of foreign nationals, foreign organizations and foreign legal entities of national or international scale, the management and development of said waqf property may be carried out by the Indonesian Waqf Board; 5) In the case of waqf property originating from abroad, the waqf must complete with proof of legal ownership of waqf property in 
accordance with statutory provisions, and nadzir must report to the relevant agency regarding the existence of waqf acts; 6) Management and development of waqf property is carried out with the following conditions: a) must be guided by the regulations of the Indonesian Waqf Board (BWI); b) management and development of endowment assets can only be done through investments in Islamic Financial Institution products or Islamic financial instruments; c) in the event that the Sharia Financial Institution Receiving Money Waqf (LKS-PWU) receives a cash waqf for a certain period of time, the Nazir can only manage and develop the assets of the endowment of the cash waqf at the LKS-PWU; d) management and development of waqf assets carried out at Islamic banks must follow the deposit insurance program in accordance with statutory regulations; e) management and development of waqf assets made in the form of investments outside the Islamic bank must be insured with Islamic insurance.

\section{METHODOLOGY Research Approach}

This research is a qualitative study using grounded research methods that moves from the empirical level to the conceptual-theoretical level. This was done with the aim of building a theory through empirical exploration of the economic empowerment of productive waqf conducted by the Baznas Tasikmalaya City.

\section{Source and Data Collection}

Sources of data in this study consisted of primary data sources, namely Baznas City of Tasikmalaya, Ministry of Religion of Tasikmalaya City in the field of zakat and endowments, waqf, and surrounding communities. While the secondary data source is in the form of documents. Data collected through: I) indepth interviews with nadzir waqf, business managers and parties with an interest in developing productive waqf. 2) Observation by observing the activities of productive waqf economic empowerment in the pilot project to complete the required data.

\section{Data Analysis Technique}

Data analysis was carried out qualitatively with the following stages of data analysis: I) at the describing stage, the researcher explored data collection in general in various aspects concerning the empowerment of productive waqf economics in the pilot project conducted by Baznas in Tasikmalaya City; 2) the classifying or 
categorizing stage, at this stage the researcher makes a description of the data based on the classification of the data by paying attention to the concepts and the potential for empowering productive waqf; 3) at the last stage of data analysis, namely the stage of connecting researchers to construct by connecting categories related to the economic empowerment of productive waqf so that a complete description can be made about the empowerment of productive waqf economics so that in the end a conclusion can be drawn.

\section{RESULTS AND DISCUSSION \\ Profil of Madina Minimarket}

The establishment of Madina Minimarket is one form of the implementation of the empowerment of productive waqf funds by Baznas Tasikmalaya City. Starting from the concept that was designed and discussed to build local economic resilience and optimize the potential of the local economy that has an impact on society. The initial draft of this idea was discussed by the Chairman of Baznas Tasikmalaya City with one of his colleagues in the City of Medina (KSA), so that the minimarket was named Madina. At the beginning of September 20I5, Madina Minimarket construction began as a pilot project with a location on J1. Purbaratu, Kp. Cihaji Kaler RT. 002/RW. 013, Kelurahan Sukanagara, Kecamatan Purbaratu, Kota Tasikmalaya. On November 29, 2015 the grand opening of the Madina Minimarket was held, which was attended by Budi Budiman as Mayor of Tasikmalaya and scholars (ulama) from Tasikmalaya City.

Madina Minimarket is an example of empowering waqf based on local economic development conducted by Tasikmalaya City Baznas. Madina Minimarket in addition to building local economic resilience, also develops businesses whose profits are used for social activities, namely providing social funds to mosques in Purbaratu District in the form of shopping vouchers for mosque needs and preacher welfare. The expectation of the Baznas Tasikmalaya City after successfully implementing the productive waqf funds can also be done in other districts in Tasikmalaya City environment. So that this productive waqf fund can really be empowered to improve the Ummah economy.

Madina Minimarket builds a franchise brand with the concept of a modern department store that is $100 \%$ owned by the community. A business innovation as an implementation of the empowerment of productive waqf funds oriented to positive socio-economic impacts and directly to the prosperity of the mosque and the local economy. Madina as a local minimarket, develops its know-how and management independently and is developed by local entrepreneurs of Tasikmalaya 
City who are able to create a regional business style that is of a national standard.

\section{Management of Waqf Business at Madina Minimarket}

Waqf funds received by Baznas Tasikmalaya City were used as fixed capital in the form of land and buildings in the Minimarket Madina. While for working capital of Rp. 500.0000.000, - they obtained from a social investor an entrepreneur in Purbaratu. The management of Madina Minimarket business is fully left to Madina Minimarket Manager, so that the manager has full responsibility for the operational mechanism of the business which is responsible to Baznas Tasikmalaya in the form of financial reports that must be submitted every month. Baznas also acts as a supervisor in the implementation of the development of productive waqf funds in the form of a minimarket business. Madina Mini Market during the period 2016 - 2019 experienced an increase in turnover. This can be seen in the following picture:

\section{Picture 2}

\section{Increased Madina Minimarket Turnover}

Period 2016 - 2019

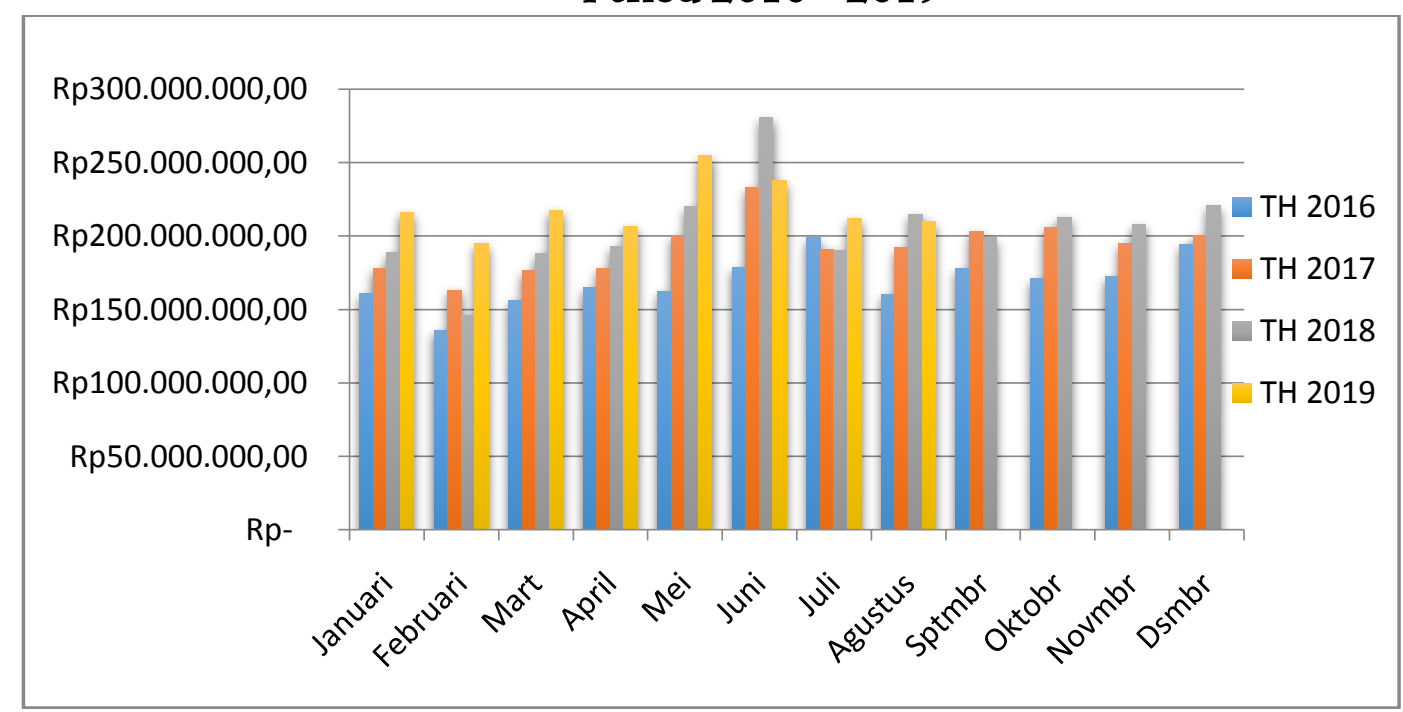

Source: Madina Minimarket 


\section{Product sold at Madina Minimarket}

The products provided are for people's (community) daily needs, like most minimarkets. Products sold by Madina Minimarket, in addition to collaboration with minimarket suppliers, also sell local Micro, Small and Medium Enterprises products with the aim of helping to develop the economic level and economic potential of the surrounding community. In addition, the products sold by Madina Mini Market prioritize the aspects of halal principles and avoid selling products that are prohibited by sharia, such as alcoholic beverages, cigarettes, etc.

\section{Madina Minimarket Target Consumers}

The target consumers are the communities around Madina minimarket and the worshipers of the mosque in Purbaratu Subdistrict. Therefore, marketing and sales promos are carried out by religious teachers (ustadz) and mosque managers respectively through the respective mosque taklim assemblies in Purbaratu District of Tasikmalaya City. In a study conducted by Suryanto in Tasikmalaya City, mosque takmir activities which can be used as a promotional target for the Madina Mini Market are Majelis taklim ranging from youth and youth recitation groups, housewives, and fathers (Asep Suryanto, at. al., 2016).

\section{Madina Minimarket Profit Distribution}

The profit earned by Madina Minimarket is used to pay the salaries of employees and is routinely distributed every month to mosques in the form of shopping vouchers for the needs of mosque facilities and the welfare of Jum'ah prayer khatib. Funds distributed to the mosques are in the form of shopping vouchers worth Rp. 200,000 per month with a time limit of one month. If the shopping voucher is not spent within I (one) month I (one) week, then the shopping voucher is considered forfeited which will then be accumulated by Madina Minimarket as funds to be distributed back to the mosques for the following month. 
Table I

Mosque Welfare Fund 2016 - 2019

\begin{tabular}{|c|c|c|c|}
\hline 2016 & 2017 & 2018 & 2019 \\
\hline Rp 3,400,000.00 & Rp $6,000,000.00$ & & Rp 2,000,000.00 \\
\hline Rp 3,400,000.00 & Rp 5,000,000.00 & $\mathrm{Rp} 4,000,000.00$ & Rp $1,000,000.00$ \\
\hline $\operatorname{Rp} 3,400,000.00$ & Rp $5,000,000.00$ & $\mathrm{Rp} 4,000,000.00$ & $\operatorname{Rp} 2,000,000.00$ \\
\hline $\mathrm{Rp} 3,400,000.00$ & Rp 5,000,000.00 & $\mathrm{Rp} 4,000,000.00$ & $\mathrm{Rp} 2,500,000.00$ \\
\hline Rp 3,400,000.00 & $\mathrm{Rp}_{\mathrm{p}} 5,000,000.00$ & $\mathrm{Rp} 4,000,000.00$ & Rp 2,600,000.00 \\
\hline Rp 3,400,000.00 & Rp 5,000,000.00 & $\mathrm{Rp} 4,000,000.00$ & Rp 2,600,000.00 \\
\hline $\mathrm{Rp} 3,400,000.00$ & $\mathrm{Rp} 5,000,000.00$ & $\mathrm{Rp} 3,000,000.00$ & $\mathrm{Rp} 2,600,000.00$ \\
\hline Rp 3,400,000.00 & Rp 5,000,000.00 & $\mathrm{Rp} 4,000,000.00$ & Rp 2,600,000.00 \\
\hline Rp 4,000,000.00 & Rp 7,000,000.00 & Rp $4,000,000.00$ & $\mathrm{Rp}$ \\
\hline Rp $4,000,000.00$ & $\mathrm{Rp}_{7,000,000.00}$ & $\mathrm{Rp}$ & $\mathrm{Rp}$ \\
\hline $\mathrm{Rp} 4,000,000.00$ & Rp 7,000,000.00 & $\mathrm{Rp}$ & $\mathrm{Rp}$ \\
\hline Rp 4,000,000.00 & RpI0,600,000.00 & Rp 4,000,000.00 & $\mathrm{Rp}$ \\
\hline Rp 3,200,000.00 & Rp $62,000,000.00$ & Rp $35,000,000.00$ & Rp I7,900,000.00 \\
\hline \multicolumn{2}{|c|}{ Total } & $\mathrm{Rp}$ & I58,I00,000.00 \\
\hline
\end{tabular}

Source: Madina Mini Market Report

The number of Mosque Prosperity Councils (DKM) in Purbaratu District is 58 mosques. However, not all mosques in Purbaratu District get the distribution of business results from productive waqf funds conducted by Madina Minimarket. It really depends on the fluctuations in profits per month obtained by Madina Minimarket. Therefore, the profit distribution is only able for 20 Mosque Prosperity Councils. If there is an increase in Madina Minimarket profit, the number of Masjid Prosperity Board as recipients of shopping vouchers will increase.

The business mechanism and profit distribution of Madina Minimarket can be described as follows: 


\section{Picture 3}

\section{Business Mechanisms and Profit Distributionof Madina Minimarket}

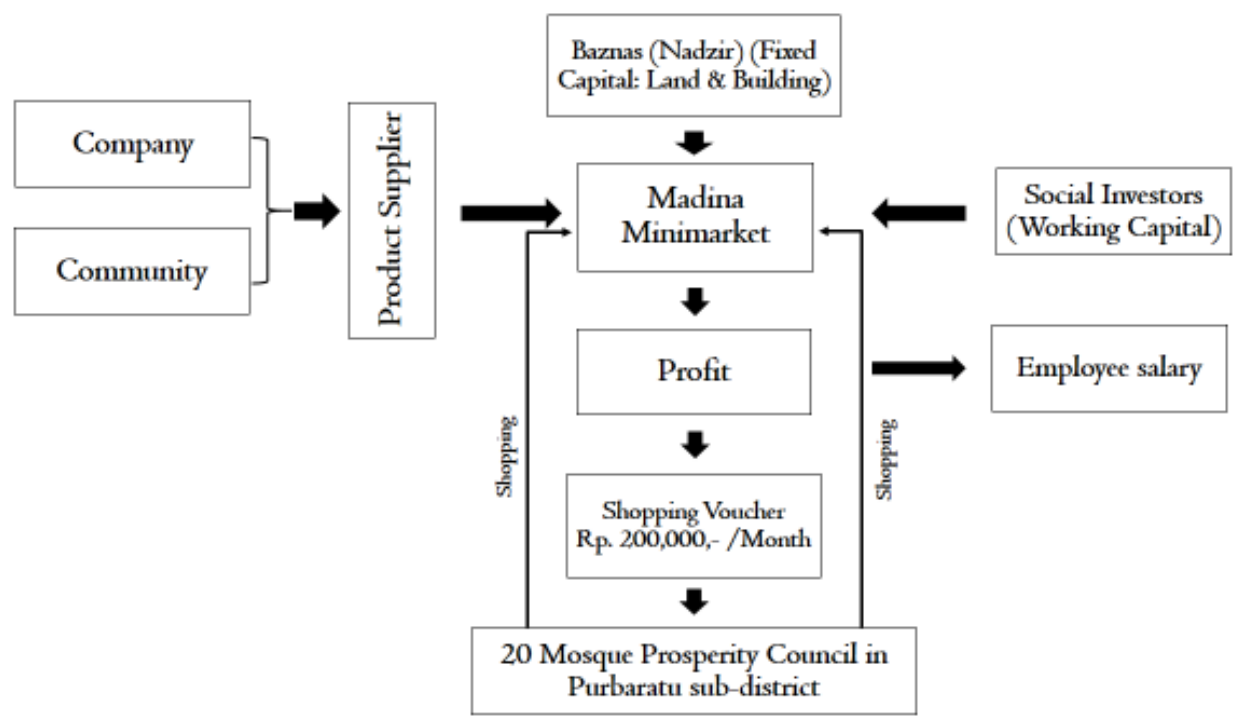

\section{E. CONCLUSION}

Based on the results of studies in the field regarding the economic empowerment of productive waqf in City of Tasikmalaya it can be concluded as follows:

The potential of waqf in Tasikmalaya City is quite large, but almost all of the waqf assets are in the form of land. Utilization of waqf assets in the form of land in Tasikmalaya is mostly used to build educational facilities both mosques, madrasas, and Islamic boarding schools. While the utilization for the benefit of business development is still relatively small, one of which is the waqf managed by City of Tasikmalaya Baznas in the form of land assets which are then utilized by building a Madina minimarket with the help of venture capital from local community leaders.

The proceeds from the minimarket's income besides being used to pay employees are also distributed to mosques in Purbaratu sub-district in the form of shopping vouchers for mosque needs with a voucher amounting to Rp. 200,000,each mosque. 


\section{REFRENCES}

Ahmed, Habib. (2007), "Waqf-Based Microfinance: Realizing The Social Role of Islamic Finance", International Seminar on Integrating Awqaf in the Islamic Financial Sector, Singapore, Jeddah, pp. I-22

Aimi, Noor Bt Mohd Puad, at all, (20I4), "Issues and Challenges of Waqf Instrument : A Case Study in MAIS", E-Proceedings of the Conference on Management and Muamalah (CoMM), pp. II6-I27

Amuda, Yusuff Jelili, (2013),"Empowerment of Nigerian Muslim Households through Waqf, Zakat, Sadaqat and Public Funding", International Journal of Trade, Economics and Finance, Vol. 4, No. 6, pp. 4I9-424

Ayub, Hasan. (2006), Fiqh Muamalah Maliyah fil Islam, Kairo : Dar as Salam.

Az Zuhaily,Wahbah. (1985), Fiqh Islam wa Adillatuhu, Damaskus : Dar al-Fikr.

Bayinah, Ai Nur. (20I2),"Exploring and Empwering Waqf Invesment Toward an acceleration of Economic development in Indonesia", Conference Proceedings, Annual International Conference on Islamic Studies (AICIS XII), Surabaya - Indonesia, pp. 268I-2707

Directorate General of Islamic Community Guidance. Ministry of Religion of the Republic of Indonesia. (2018).

Ismail, Muhammad bin. (1995),Subulus Salam Syarah Bulughul Marom Min Jam'í Asillatil Ahkam, Muhaqqiq: Hazim Ali Bahjat al-Qodhi, Riyadh-Arab Saudi: Maktabah Nazar Musthofa Al-Baz.

Praja, Juhaya S., Muzarie Mukhlisin. (2009),Islamic Economics Institution of Waqf, Cirebon: STAIC Press.

Purnamasari, F. (2020). Competitive Advantage Towards Creative Economy in Islam. Journal of Islamic Business and Economic Review, 3(I).

Ramli, Asharaf Mohd; Abdullaah Jalil. (2013), "Corporate Waqf Model and Its Distinctive Features: The Future of Islamic Philanthtopy", Paper presented at the World Universities Islamic Philanthrophy Conference, Menara Bank Islam, Kuala Lumpur, pp. I-I4

Rusydiana, Aam Slamet, at. all. (2019), "Manakah Prioritas Sektor Pengembangan Wakaf di Indonesia?", Al-Masraf: Jurnal Lembaga Keuangan dan Perbankan, Vol.4, No.I, pp. 7-I6.

Saad, Norma Md, et. al. (2017),"Managing Corporate Waqf in Malaysia : Perspectives of Selected SEDCs and SIRCs”, Shariah Joumal, Vol. 25, No. I, pp. 9I-II6 
Shirazi, Nasim Shah.(20I4), "Integrating Zakāt and Waqf into the Poverty Reduction Strategy of the IDB Member Countries", Islamic Economic Studies Vol. 22, No. I, pp: 79-I08

Suryanto, Asep, at.all. (2016), " Optimalisasi Fungsi dan Potensi Masjid: Model Pemberdayaan Ekonomi Masyarakat Berbasis Masjid di Kota Tasikmalaya." Iqtishoduna: Jurnal Ekonomi Islam, Vol. 5, No. 2, pp. I-27.

Yusuf, Muhammad. (2009),Pemberdayaan Wakaf Produktif Untuk Pemberdayaan Ekonomi Umat, Semarang: Badan Wakaf Nusantara. 
Islamic Philanthropy : Waqf Empowerment of Madina Minimarket in Tasikmalaya, Indonesia Asep Suryanto ${ }^{1}$,Biki Zulfikri Rahmat ${ }^{2}$ Lina Marlina $^{3}$ 